\title{
Ipilimumab treatment results in an early decrease in the frequency of circulating granulocytic myeloid derived suppressor cells as well as their arginase 1 production
}

\author{
Giusy Gentilcore ${ }^{1 *}$, Coaña Pico de Yago ${ }^{1}$, Isabel Poschke ${ }^{1,2}$, Yumeng Mao ${ }^{1}$, Maria Nyström¹, Johan Hansson ${ }^{1}$, \\ Giuseppe V Masucci', Rolf Kiessling ${ }^{1}$
}

From Melanoma Bridge meeting 2013

Naples, Italy. 5-8 December 2013

\section{Background}

Ipilimumab (Yervoy) is a fully human antibody that blocks CTLA-4 and has proven to extend overall survival in patients with unresectable stage III or stage IV melanoma [1]. Immune related adverse effects (IRAE) are frequent and can be severe but are reversible with early diagnosis and can be managed with corticosteroid therapy [2]. Most of the recently published immune monitoring studies focus mainly on the effect that ipilimumab has on $\mathrm{T}$ cell populations[3]. To date, little information is available on the possible impact that ipilimumab treatment may have on MDSC populations and their suppressive mechanisms[4]. In order to evaluate these effects, we conducted an in-depth immune monitoring study centered on peripheral blood MDSC populations as well as $\mathrm{T}$ cells in advanced melanoma patients undergoing treatment with ipilimumab.

\section{Materials and methods}

Fourteen patients with advanced stage melanoma received ipilimumab treatment at $3 \mathrm{mg} / \mathrm{kg}$ or $10 \mathrm{mg} / \mathrm{kg}$ doses and six of which were part of an ongoing double blind randomized trial (Bristol-Myers Squibb trial CA184-169). Blood samples were collected from each patient before treatment (baseline) and at the time of the second and fourth ipilimumab doses ( 3 and 9 weeks after the first dose). Peripheral blood mononuclear cells were isolated by density gradient centrifugation and

\footnotetext{
* Correspondence: giusy.gentilcore@gmail.com

'Department of Oncology and Pathology, Cancer Center Karolinska,

Karolinska Institutet, Stockholm, Sweden

Full list of author information is available at the end of the article
}

stained for multicolored flow cytometric analysis. The staining protocol included five 9-color panels to analyze $\mathrm{T}$ cells (relative frequencies, activation, memory and Tregs) and MDSCs.

\section{Results}

Absolute lymphocyte counts showed an increasing trend during the course of treatment without significant differences. Analysis of circulating Treg (CD4+ CD25+ $\mathrm{CD} 127$ lo FoxP3+) frequencies revealed an initial increase, significantly decreasing after the second ipilimumab dose (week 9). The endpoint mean frequency of Tregs was lower than the baseline. Changes in MDSC populations with granulocytic and monocytic phenotype (Lin- HLADR-/lo CD15+ CD33+ CD11b+ and Lin- HLA-DR-/lo CD14+, respectively) were monitored and the results showed that, after the first dose, the granulocytic MDSC population significantly decreased, remaining low at week 9 . This decrease was accompanied by a significant decrease in the population of ARG1+ myeloid cells.

\section{Conclusion}

The results shown in this work provide a first look at the early responses of peripheral blood myeloid cell populations to ipilimumab treatment. The mechanisms by which these in trans effects are taking place should be further explored as well as their possible relations to clinical benefit.
Authors' details

'Department of Oncology and Pathology, Cancer Center Karolinska, Karolinska Institutet, Stockholm, Sweden. ${ }^{2}$ Division of Molecular Oncology of 


\section{References}

1. Hodi FS, O'Day SJ, McDermott DF, Weber RW, Sosman JA, Haanen JB, Gonzales R, Robert C, Schadendorf, Hassel JC, Akerley W, van den eertwegh AJ, Lutzky J, Lorigan P, Vaubel JM, Linette GP, Hogg D, Ottensmeier CH, Lebbè C, Peschel C, Quirt I, Clark Jl, Wolchok JD, Weber JS, Tian J, Yellin MJ, Nichol GM, Hoos A, Urba WJ: Improved survival with ipilimumab in patients with metastatic melanoma. N Engl J Med 2010, 363:711-23.

2. Fellner C: Ipilimumab (Yervoy) Prolongs Survival In Advanced Melanoma: Serious Side Effects and a Hefty Price Tag May Limit Its Use. P T 2012, 37:503-30.

3. Kavanagh B, O'Brien S, Lee D, Hou Y, Weinberg V, Rini B, Allison JP, Small EJ, Fong L: CTLA4 blockade expands FoxP3+ regulatory and activated effector CD4+ T cells in a dose-dependent fashion. Blood 2008, 112:1175-83.

4. Poschke I, Kiessling R: On the armament and appearances of human myeloid-derived suppressor cells. Clin Immunol 2012, 144:250-68.

doi:10.1186/1479-5876-12-S1-09

Cite this article as: Gentilcore et al.: Ipilimumab treatment results in an early decrease in the frequency of circulating granulocytic myeloid derived suppressor cells as well as their arginase 1 production. Journal of Translational Medicine 2014 12(Suppl 1):09.

\section{Submit your next manuscript to BioMed Central and take full advantage of:}

- Convenient online submission

- Thorough peer review

- No space constraints or color figure charges

- Immediate publication on acceptance

- Inclusion in PubMed, CAS, Scopus and Google Scholar

- Research which is freely available for redistribution

Submit your manuscript at www.biomedcentral.com/submit 